\title{
Effects of selected Taiwanese endemic plants on anti-lipid peroxidation and antibacterial activities against clinically isolated extended-spectrum- $\beta$ - lactamase producing Klebsiella pneumoniae and Escherichia coli
}

\section{Po-Wei Tsai}

Chang Jung Christian University College of Health Sciences

Pei-Chin Lin

Far Eastern Memorial Hospital

\section{Ling-Ling Yang}

Taipei Medical University

Ming Shun Wu ( $\nabla$ vw1017@gmail.com )

Taipei Medical University https://orcid.org/0000-0002-5755-9062

\section{Research Article}

Keywords: Extended-spectrum- $\beta$-lactamase, Klebsiella Pneumoniae, Escherichia coli, Lipid peroxidation, Rhus semialata var. roxburghiana

Posted Date: March 8th, 2021

DOl: https://doi.org/10.21203/rs.3.rs-168014/v1

License: (c) (1) This work is licensed under a Creative Commons Attribution 4.0 International License. Read Full License 


\section{Abstract}

It has been a challenge for many clinicians to treat a complicated extended-spectrum- $\beta$-lactamase (ESBL) producing Klebsiella Pneumoniae (Kp) and Escherichia coli (E. coli) infection due to widespread antibiotic abuse with renal damage as one of its common side effects. Therefore, this study aimed to assess the antibacterial activity of extracts from several Taiwanese folk medicinal plants against ESBL- $K p$ and $E$. coli. with renal protecting ability against lipid peroxidation (LPO) on mice kidney mitochondria.

Preliminary antibacterial activities of ethanol extracts from twenty (20) Taiwanese folk medicinal plants were measured by agar-dilution method against standard ESBL strains of E. coli (ATCC 25922, ATCC 35218) and Kp (ATCC 23856, ATCC 700603). Rhus semialata var. roxburghiana DC. (RSR) exerted the most inhibitory effect and then further extracted with $n$-hexane, ethyl acetate, acetone, ethanol, and water, respectively. Each extract also evaluated against the four standard ATCC microorganisms. Their $\mathrm{MIC}_{50}$, $\mathrm{MIC}_{90}$, and time kill assay were adapted with detecting the maximum inhibitory activities and the antibacterial spectrum range of each extract was measured against twenty-four (24) kinds of microbes. Which were used including gram-positive, gram-negative bacteria and fungus by agar dilution method. Finally, renal protective ability was detected inhibitory effect of ferrous induced lipid peroxidation on mice mitochondria. Among 20 Taiwanese folk medicinal plants tested, Rhus semialata var. roxburghiana DC. (RSR) exhibited maximum inhibition against clinical ESBL-producing $K p$ and $E$. colistrains with acetone extracts showing $\mathrm{MIC}_{50} / \mathrm{MIC}_{90}$ values at $1000 \mu \mathrm{g} / \mathrm{mL}$, the course of antimicrobial action was bacteriostatic and with inhibitions to all 24 kinds of microbial including Gram positive and negative bacteria and fungi. Furthermore, result of thiobarbituric acid reactive substances (TBARS) assay from this extract showed high lipid peroxidative (LPO) protective capability on mice kidney mitochondria $\left(\mathrm{IC}_{50}\right.$ : $29.29 \pm 0.35 \mu \mathrm{g} / \mathrm{mL}$ ). RSR acetone extract, with its maximum activity against clinical isolated ESBLproducing $K p$ and $E$. coli, antimicrobial effect against other wide spectral range bacteria and relatively high LPO protective ability on mice kidney mitochondria, is a potential source, albeit further studies have yet to be conducted, to develop an antimicrobial drug against ESBL-Kp and E. coli.

\section{Introduction}

Medicinal plants have been the major source of new medicines and offer an alternative to usual drugs (Tepe at al., 2004). As the primary source for human treatment, World Health Organization (WHO) reported that approximately $80 \%$ of the world population relies on plants or derived products (WHO, 1993). In case of infectious diseases, one of the reasons of unsuccessful treatment could be attributed to increasing number of drug-resistant bacteria (Al-Mariri and Safi, 2014). This indeed is associated with the potencies of existing antibiotics are decreasing steadily (Shahghasi et al., 2004). Since multidrug resistance of microorganisms is a major medical concern, screening of natural products in search for new antimicrobial agents is the need of the hour (Zgoda and Porter, 2001).

Treatment of complicated extended-spectrum- $\beta$-lactamase (ESBL) Klebsiella Pneumoniae (Kp) and Escherichia coli infection is a challenging for clinicians due to the antibiotic abuse (Hoban et al., 2001) 
(Sah et al., 2019)(Tan et al., 2020). ESBL-producing bacteria is able to hydrolyze third-generation cephalosporin, aminoglycoside and fluoroquinolone (Harish et al., 2007). Kp and E. coli are normal flora in human intestine. $K p$ is a frequent agent causing nosocomial or community-acquired bacteraemia as well as pneumonia, pyogenic brain abscess, meningitis, and pyogenic liver abscesses (Tsai et al., 2010) (Hui et al., 2007). ESBL- E. coli urinary tract infection is increasing, and in more serious cases, the bacteria enter the bloodstream and cause toxemia. (Rodríguez-Baño et al., 2004). Several studies have been reported that utilizes antibacterial properties of plant extracts against $K p$ and $E$. coli (Sharmeen et al., 2012)(Shaik et al., 2014)(Haroun and Al-Kayali, 2016). Moreover, renal damage is one of the side effects of antibiotics therapy with increasing possibility leading to acute renal failure in newborn (Fanos and Cataldi, 1999). In Taiwan, the risk of end-stage renal disease (ESRD) increased among those that reported regular use of antibiotics and has become another public health problem shouldered by the health insurances on medicinal care (Tsai et al., 2009).

Twenty (20) plant extracts, some are endemic in Taiwan, were collected with extracts have been traditionally employed in Taiwan as detoxicant. This study aimed to investigate these Taiwanese folk medicinal plants for their antimicrobial activities that can be utilized for the development of potential antimicrobial agent against the antibiotic-resistant bacteria -ESBL-producing $K p$ and $E$. coli with kidney protective activity.

\section{Material And Method}

\section{Herbal Materials}

Twenty (20) kinds of dried Taiwanese folk medicinal plants with antitoxic ability were purchased from the crude drug market in Taipei, Taiwan: Amaranthus viridis Linn., Angelica dahurica var. formosana Yen, Bidens pilosa L. var. minor (blume) Sherff, Broussonetia papyrifera (Linn) L'Herit. Ex Vent., Centella asiatica L., Equisetum ramosissimum subsp..debile (Roxb.) Hauke., Euphorbia hirta L., Euphorbia thymifolia L., Eupatorium formosanum Hay., Kyllingia brevifolia Rottb., Litsea cubeba (Lour.) Pers., Persoon Actinodaphne citrata (Blume) Hayata, Lygodium japonicum (Thunb.) Sw., Pinellia ternate (Thunb.) Breit., Plantago asiatica L., Polygonum perfoliuatum Linn., Portulaca oleracea var. sativa DC., Pteris multifida Poir., Rhus semialata var. roxburghiana DC., Serissa japonica (Thunb.) Thunb., Urena lobata L.. All were identified by Prof. Ling-Ling Yang and the specimens were stored at the Department of Pharmacognosy, Taipei Medical University.

\section{Microorganisms}

Twenty-eight (28) kinds of standard microorganism were purchased from Food Industry Research and Development Institute (FIRDI) in Taiwan. Standard strains include Klebsiella Pneumoniae ATCC 23856, (ESBL) ATCC 700603, Escherichia coli ATCC 25922, ATCC 35218, Staphylococcus. aureus (MSSA) ATCC 29213, (MRSA) 85/2082, (hVISA) Mu3, (VISA) Mu50, Staphylococcus epidermidis ATCC 12228, Group B streptococcus ATCC 12401, Enterococcus faecalis ATCC 29212, ATCC 29212, Pseudomonas aeruginosa ATCC 14207, ATCC 27853, Samonella enteric Typhimurium ATCC 13076, Samonella multivorum ATCC 
35656, Samonella typhimurium ATCC 13311, Samonella paratyphi (A) ATCC 9150, Samonella anatum (E) ATCC 9270, Samonella choleraesusis ATCC 10744, ATCC 115462, Shigella boydii ATCC 9207, Shigella dysenteriae ATCC 13983, Shigella flexneri ATCC 10772, Shigella sonnei ATCC 15965, ATCC 25931, Candida albicans ATCC 90018, Candida parapsilosis ATCC 22019. While the thirty-three (33) clinical strains were isolated and collected from Wan Fang Hospital, Taipei Medical University, Taipei, Taiwan, which labeled as Klebsiella Pneumoniae (ESBL) 1520914, 1527226, 1527920, 1520160-1, 1521656, $1522657,1523941,1524581,1526783,1543407,1541487,1542299,1545756,80,81,91,98$, and Escherichia coli (ESBL) 1526829, 1522652, 1530404, 1521949, 1521624, 1521569, 1530090, $1520331,1520641,1522991,1522953,1519678,1520264,1527958,1528051,1527082)$.

\section{Chemicals and reagents}

All chemicals and reagents were analytical grade including dimethyl sulfoxide (DMSO), gallic acid, FolinCiocalteu's reagent, rutin, aluminum chloride, epicatechin, ferrous chloride $\left(\mathrm{FeCl}_{2}\right)$, trolox, 2-thiobarbituric acid (TBA), 1,1,3,3-tetraethoxypropane (TEP), bovine serum albumin, phosphoric acid, methanol, sodium hydroxide $(\mathrm{NaOH})$ and 4-dimethylaminocinnamaldehyde (DMACA) were purchased from Sigma Chemical (St. Louis, MO).

\section{Animals}

Imprinting Control Region (ICR) mice were purchased from BioLASCO Taiwan Co., Ltd., housed in plastic cages in a temperature and humidity-controlled environment and bred at the Experimental Animal Center of Taipei Medical University. All experiments were approved and performed in accordance with the guidelines for Experiments Animal Center of Taipei Medical University and the Laboratory Animal Ethics Committee of Taipei Medical University with the guiding principles for the care and use of laboratory animals approved by the Chinese Society of Laboratory Animal Sciences, Taiwan (No. LAC980119). All efforts were made to minimize animal suffering and to reduce the number of animals used.

\section{Extraction and sample solution preparation}

Dried plants were washed continuously with tap water to remove impurities, cut into small pieces and then dried in the air circulating oven at $60^{\circ} \mathrm{C}$ for $48 \mathrm{hr}$. Each $100 \mathrm{~g}$ of dried material was extracted twice with $1000 \mathrm{~mL}$ of ethanol, filtered, and combined the filtrates, then concentration and removed the solvent in vacuo by vacuum rotary evaporator (Eyela CCA-1111) to $50 \mathrm{~mL}$. The concentrated extract solutions were dried by lyophilizer (Eyela FDU-1200) to obtain the extract. The preliminary antimicrobial activity to standard strains of $K p$ and E. coli ATCC bacteria of each extract was identified to find RSR the most potent extract from the 20 Taiwanese endemic plants. Therefore, RSR was further extracted by $n$-hexane, ethyl acetate, acetone, ethanol and water, respectively. Each crude extract $(20 \mathrm{mg})$ was dissolved in $1 \mathrm{~mL}$ DMSO as a stock solution and serial dilution with PBS for the following assays. ( DMSO $<0.05 \%$ ).

\section{Protocol of an antimicrobial agent development from natural plants source procedure}


Five (5) steps were carried out to determine the most potent extract with antibacterial capability against $K p$ and $E$. coli and renal damage protective effect (Figure 1). Agar-dilution method was used to preliminary screening assess the antibacterial activity of crude extracts from 20 Taiwanese plants against standard strains of Kp and E. coli ATCC bacteria (E. coli ATCC 25922, ATCC 35218 and Kp ATCC 23856, ATCC 700603). RSR crude extract exhibited the maximum inhibitory effects and then subjected to further extract by $n$-hexane, ethyl acetate, acetone, ethanol and water, respectively. Each of these extracts was prepared as mentioned previously prior to antimicrobial assay against the same 4 bacteria by agardilution method.

The most potential extract of RSR (acetone extract) was chosen to evaluate the $\mathrm{MIC}_{50}$ and $\mathrm{MIC}_{90}$ against clinical $K p$ and E. coli. Time kill assay against $K p$ (ATCC) 23856, (ATCC) 700603, E. coli (ATCC) 25922, (ATCC) 35218, and clinical ESBL-Kp 1520914 and ESBL-E. coli 1526829 were also conducted.

To assess the antibacterial spectral range of the extract, agar-dilution method was performed against 24 kinds of microbes including Gram positive, gram negative bacteria and fungi. Finally, the renal protective capability was measured by ferrous ion-induced lipid peroxidation (LPO) on mice mitochondria.

\section{Agar-dilution method}

Agar-dilution method described by Nauman and Arshad (2011) was used with some modification. Briefly, extracts were added in appropriate amounts of $20 \mathrm{~mL}$ Mueller-Hinton (MH) agar to yield a two-fold serial dilution. The bacteria were plated onto the $\mathrm{MH}$-agar surface $\left(10^{4} \mathrm{CFU}\right.$ per $0.3 \mu \mathrm{L}$ per spot) by an A400 Multipoint Inoculators (Jencons Co. UK) and incubated at $37^{\circ} \mathrm{C}$ for 24 hours. MIC value was evaluated as the lowest concentration $(\mu \mathrm{g} / \mathrm{mL})$ of antimicrobial agent with no visible growth. $\mathrm{MIC}_{50}$ and $\mathrm{MIC}_{90}$ were detected with the concentration of antibacterial agent preventing $50 \%$ and $90 \%$ of colony formation of the strains tested.

\section{Time-kill assay}

Method as described by Darah et al. (2013) was used with some modification. Briefly, exponential-phase ESBL-producing Kp (ATCC) 23856, (ATCC) 700603, E. coli (ATCC) 25922, (ATCC) 35218, and clinical ESBL-Kp 1520914 as well as ESBL- E. coli 1526829 were diluted to $4 \times 10^{4}$ to $1 \times 10^{5} \mathrm{CUF} / \mathrm{mL}$ and then exposed to RSR acetone extract (1,2 and $4 \times$ MIC), $1 \mathrm{~mL}$ DMSO, polymyxin B sulfate salt (PB) $(0.5$ and $1 \times \mathrm{MIC}$ ) and $1 \times$ MIC RSR acetone extract combined with $0.5 \times$ MIC PB, respectively, incubated for 48 hours period in a total volume of $2 \mathrm{~mL}$ of $\mathrm{MH}$ media. Viable cell count was determined by agar plating (onto $\mathrm{MH}$ agar). Bactericidal activity was defined as $>3 \log$ decrease in cell counts. For all strains in the present report, time kill assays were performed at least twice independently with similar results.

\section{Inhibitory capability of LPO on mice kidney mitochondria}




\section{Preparation of mice kidney mitochondria and protein content quantitation}

Method described by Lin et al. (2013) was used with some modification. Male ICR mice (4 6 weeks) were sacrificed by carbon dioxide and the kidneys were removed as soon as possible and perfuse with ice-cold PBS (0.1 M, pH 7.4) prior to homogenizing in a Potter Elvehjem homogenizer. The homogenate was suspended in PBS and centrifuged at $2000 \mathrm{rpm}$ for $10 \mathrm{~min}$ at $4^{\circ} \mathrm{C}$ to separate the nuclear debris. The clear suspensions were re-centrifuged at $13000 \mathrm{rpm}$ for $10 \mathrm{~min}$ at $4^{\circ} \mathrm{C}$ to obtain mitochondrial fraction and then suspended in PBS. Different concentrations of mitochondrial suspended solution were pipetted into $1.5 \mathrm{~mL}$ eppendorf tubes, and total volume was adjusted to $50 \mu \mathrm{L}$ with PBS. Protein reagent was added and mixed with a vortex-mixer before measurement of absorbance at $595 \mathrm{~nm}$ by ELISA spectrophotometer (Synergy H4 Hybrid Reader). Quantitative analysis of the protein content was determined from bovine serum albumin standard curve.

\section{Inhibitory capability of RSR (Rhus semialata var. roxburghiana) acetone extract on ferrous chloride induced LPO production in mice kidney mitochondria}

The LPO inhibitory activity was determined by thiobarbituric acid reactive substances (TBARS) assay by quantitatively measure the MDA(TBA) $)_{2}$ products using ELISA reader (Synergy H4 Hybrid Reader). The reaction mixture solution (total volume of $500 \mu \mathrm{L}$ ) containing $100 \mu \mathrm{L}$ of kidney mitochondria, $200 \mu \mathrm{L}$ of PBS buffer, $100 \mu \mathrm{L}$ of an $\mathrm{FeCl}_{2}$ solution $(4 \mathrm{mM})$, and $100 \mu \mathrm{L}$ of RSR acetone extract or positive control (trolox or gallic acid) was incubated at $37^{\circ} \mathrm{C}$ for 1 hour, then centrifuged at $4000 \mathrm{rpm}$ for $10 \mathrm{~min}$. A 375 $\mu \mathrm{L}$ of $\mathrm{H}_{3} \mathrm{PO}_{4}, 200 \mu \mathrm{L}$ of distilled water, and $125 \mu \mathrm{L}$ of TBA were added and the mixture was further incubated at $90{ }^{\circ} \mathrm{C}$ for $66 \mathrm{~min}$ prior to place in an ice bath to stop the reaction. Then, $350 \mu \mathrm{L}$ of methanol$\mathrm{NaOH}\left(9.1: 0.9 \mathrm{v} / \mathrm{v}\right.$ ) was added, mixed and absorbance of $\mathrm{MDA}(\mathrm{TBA})_{2}$ product was measured at $532 \mathrm{~nm}$. The data was recorded and the inhibition of LPO calculated according to the following formula:

Inhibition percentage $=\left[\left(\mathrm{A}_{\text {control }(532 \mathrm{~nm})}-\mathrm{A}_{\text {sample }(532 \mathrm{~nm})}\right) /\left(\mathrm{A}_{\text {control }(532 \mathrm{~nm})}-\mathrm{A}_{\text {blank }(532 \mathrm{~nm})}\right)\right] \times 100 \%$ while $\mathrm{IC}_{50}$ was calculated by a linear regression analysis, and results were expressed as mean $\pm \mathrm{SD}$.

\section{Results And Discussion}

Infectious diseases caused serious threats to the existence, health and survival of humans (Yamac and Bilgili, 2006). With the growing demands of search and development of new antibacterial agent against the rapid rise of antibiotic-resistant strain worldwide, studies are currently focusing on natural sources due to its efficacy, safety and cheaper nature. Medicinal plants have long been used as a source of antibacterial compounds due to its vast number and diversity of secondary metabolites. In this study, 20 Taiwanese folk medicinal plants traditionally used as detoxicant and some are endemic, were screened for antimicrobial properties against the antibiotic-resistant bacteria -ESBL-producing $K p$ and $E$. coli with kidney protective activity. 
Preliminary screening of the ethanol extracts in DMSO from 20 Taiwanese plants collected against two $K p$ and E. coli bacteria strains showed that only Rhus semialata var. roxburghiana DC. (RSR) gave a positive inhibition against $K p$ (ATCC 23856) strain but negative to other $K p$ (ATCC 700603) strain as well as E. coli (ATCC 25922 and ATCC 35218) in the preliminary screening whereas the rest of the studied extracts were all have negative inhibitions (Table 1). These results were in contrast to some previous reports from other plants screened having antimicrobial properties against other microorganisms (Baruah et al., 1994)(Williamson, 2002)(Hellión-lbarrola et al., 2012)(Shu et al., 2012)(Narasimhulu And Mohamed, 2014)(Babu et al., 2015)(Li, 2006)(Zhao et al., 2016)(Subba et al., 2016)(Syed et al., 2016). Klebsiella spp are known opportunistic pathogens naturally present in soil, water and vegetables that causes serious infections in human especially since this specie is becoming increasingly antibiotic-resistant, so that many are now labeled as "Multidrug-resistant (MDR) Klebshiella spp. (Yan et al., 2001)(Ktari et al., 2006) (Wei et al., 2008).

More recent studies focused on extraction of phytochemical constituents using different solvents of variable polarities to analyze their pharmacological properties. Hence, extracts from RSR where further partitioned in different solvents to obtain the crude extracts with $n$-hexane, ethyl acetate, acetone, ethanol and water, respectively, and the same antibacterial tests were applied using the same four microorganisms from preliminary screening. Results showed that all RSR extracts partitioned in solvents except in ethanol, showed inhibitions against the two Kp (ATCC 23856 and 700603) strains with high MIC value observed in the acetone extracts $(500 \mu \mathrm{g} / \mathrm{mL}$ ) against $K p$ (ATCC) 23856 (Table 2). Similarly, EA and acetone extracts gave positive inhibitions against E. coli (ATCC 25922 and ATCC 35218) except $n$-hexane extract, which gave negative inhibitions. In addition, both ethanol and water extracts exhibited negative inhibitions against all E. coli strain used. These maybe associated with the polar constituents present in the RSR acetone extracts such as phenolics that are often related to antioxidant properties. Anokwuru et al. (2013) reported that acetone is highly effective at extracting biomolecules that are antioxidant. Although there is no direct correlations between antimicrobial and antioxidant activities, many studies on plant extracts reported that biomolecules are antioxidant and antimicrobial too but further studies have yet to be conducted on these extract to validate this relationship.

Since acetone extract from RSR gave a good inhibition against the four $K p$ and $E$. coli strains, the same extract was used to evaluate its property against seventeen (17) and sixteen (16) clinically isolated $K p$ and $E$. colistrain, respectively. Results showed that acetone extract of RSR exhibited positive inhibitions against all thirty-three (33) clinically isolated $K p$ and $E$. coli strains with MIC values ranging from 500 to $1000 \mu \mathrm{g} / \mathrm{mL}$ (Table 3). No inhibitions were observed in DMSO against all the strains used.

Time-kill assay was used to assess the mode of action of RSR against the tested $K p$ and $E$. coli strains. Although time consuming, the time-kill assay provides a dynamic picture of antibiotic action over time (Perez et al., 2016). In this study, the time-kill kinetics of RSR acetone extract against Kp (ATCC) 23856 and 700603 showed a gradual increased in the number of viable cells in a dose-dependent manner, as well as when combined with polymyxin B sulfate salt (PB) (0.5X MIC) at $1 \mathrm{X}$ MIC. However, against clinical ESBL-Kp 1520914, almost same number of viable cells was observed at 4X MIC over the 
first 6 to 12 hours followed by a gradual rise up to 24 hour (Figure 2). Similar trends have been observed in the time-kill kinetics of RSR acetone extract against E. coli (ATCC) 25922 as well as when combined with polymyxin B sulfate salt (PB) (0.5X MIC) at 1X MIC. However, against (ATCC) 35218 and clinical ESBL-E. coli 1526829, almost the same number of viable cells was observed at $4 \mathrm{X}$ MIC over the first 6 hours followed by a gradual rise up at 12 hours (Figure 3). Overall, time-kill assay suggest that RSR acetone extract demonstrated a slight bacteriostatic action with strain-selectivity at relatively high MIC (4X MIC).

Disrupted balance between essentiality and toxicity of iron as an important trace element in the body is known to induce oxidative stress (OS) via Fenton reaction (Fischer et al., 2002)(Jomova and Valko, 2011) (Pari et al., 2015). Measurement of lipid peroxidase product, MDA, as the end product of poly-unsaturated fatty acid peroxidation and a marker of free radical mediated LPO injury have been applied to detect renal injury and its levels were found to significantly increase in kidney after treatment of ferrous ion indicating an increased LPO activity. In this study, LPO induced by ferrous ion on mice kidney mitochondria was significantly affected by the addition of RSR acetone extract, gallic acid and trolox in a dose-dependent manner (Table 4). However, $I_{50}$ value of the extract $(29.29 \pm 0.35 \mu \mathrm{g} / \mathrm{mL})$ is only comparable to gallic acid $(27.07 \pm 6.61 \mu \mathrm{g} / \mathrm{mL})$ than to trolox $(4.44 \pm 0.23 \mu \mathrm{g} / \mathrm{mL})$.

Antimicrobial properties of RSR acetone extract were assessed over a wide range of bacterial spectrum and fungi. Results showed that RSR acetone extract has inhibitions to all the microorganisms used (Table 5). However, positive inhibition was also observed from DMSO against Samonella multivorum, Candida albicans and Candida parapsilosis suggesting that the inhibitions observed from RSR acetone extract against these microorganisms were not purely attributed from the extract alone.

\section{Conclusions}

Out of 20 Taiwanese folk medicinal plants tested, only RSR exhibited a positive inhibition in the preliminary antimicrobial screening. RSR acetone extract, with its maximum activity against clinical isolated ESBL-producing $K p$ and E. coli, antimicrobial effect against other wide spectral range bacteria and relatively high LPO protective ability on mice kidney mitochondria, is a potential source, albeit further studies have yet to be conducted to isolate and purify the agents or molecules from this extract which is responsible for the antimicrobial properties and may serve as potential antibiotics against ESBL-Kp and E. coli.

\section{Abbreviations}

Extended-spectrum- $\beta$-lactamase (ESBL)

Klebsiella pneumoniae $(K p)$

Minimum inhibitory concentration (MIC) 
American type culture collection (ATCC)

Methicillin-sensitive Staphylococcus aureus (MSSA)

Heterogeneously vancomycin-intermediate Staphylococcus aureus (hVISA)

Methicillin-resistant Staphylococcus aureus (MRSA)

Vancomycin intermediate Staphylococcus aureus (VISA)

Vancomycin-resistant enterococci (VRE)

Mueller-Hinton agar (MH)

Mycorrhiza helper bacteria (MHB)

Lipid peroxidation (LPO)

Malondialdehyde (MDA)

Thiobarbituric acid (TBA)

Thiobarbituric acid reactive substances (TBARS)

Rhus semialata var. roxburghiana (RSR)

\section{Declarations}

\section{Conflicts of Interest}

All the authors report no conflicts of interest.

\section{References}

1. Al-Mariri A, Safi M (2014) In Vitro Antibacterial Activity of Several Plant Extracts and Oils against Some Gram-Negative Bacteria. Iran J Med Sci 39:36-43

2. Anokwuru CP, Anyasor GN, Ajibaye O, Fakoya O, Okebugwu P (2011) Effect of extraction solvents on phenolic, flavonoid and antioxidant activities of three nigerian medicinal plants. Nat Sci 9:53-61

3. Babu SS, Madhuri DB, Ali SL (2016) A Pharmacological Review of Urena Lobata Plant. Asian Journal of Pharmaceutical Clinical Research 9:20-22

4. Baruah NC, Sarma JC, Barua NC (1994) Germination and growth inhibitory sesquiterpene lactones and a flavornes from Tithonia diversifolia. Phytochemitry 36:29-36 
5. Darah I, Lim SH, Nithianantham K (2013) Effects of methanol extract of Wedelia chinensis osbeck (asteraceae) leaves against pathogenic bacteria with emphasise on Bacillus cereus. Indian journal of pharmaceutical sciences 75:533-539

6. Fanos V, Cataldi L (1999) Antibacterial-induced nephrotoxicity in the newborn. Drug Saf 20:245-267

7. Fischer JG, Glauert HP, Yin T, Sweeney-Reeves ML, Larmonier N, Black MC (2002) Moderate iron overload enhances lipid peroxidation in livers of rats, but does not affect NF-kappa B activation induced by the peroxisome proliferator, Wy-14,643. J Nutr 132:2525-2531

8. Harish BN, Menezes GA, Shekatkar S, Parija SC (2007) Extended-spectrum $\beta$-lactamase-producing Klebsiella pneumoniae from blood culture. Journal of medical microbiology 56:999-1000

9. Haroun MF, A-Kayali R (2016) Synergistic effect of Thymbra spicata L. extracts with antibiotics against multidrug- resistant Staphylococcus aureus and Klebsiella pneumoniae strains. Iran J Basic Med Sci 19:1193-1200

10. Hellión-Ibarrola MC, Montalbetti Y, Heinichen O, Kennedy M, Campuzano M, Ibarrola D (2012) Anxiolytic-like and sedative effects of Kyllinga brevifolia in mice. Rev bras Farmacogn 22:13231329

11. Hoban DJ, Doern GV, Fluit AC, Roussel-Delvallez M, Jones RN (2001) Worldwide prevalence of antimicrobial resistance in Streptococcus pneumoniae, Haemophilus influenzae, and Moraxella catarrhalis in the SENTRY Antimicrobial Surveillance Program, 1997-1999. Clin Infect Dis 32:S81S93

12. Hui JY, Yang MK, Cho DH, Li A, Loke TK, Chan JC, Woo PC (2007) Pyogenic liver abscesses caused by Klebsiella pneumoniae: US appearance and aspiration findings. Radiology 242:769-776

13. Jomova K, Valko M (2011) Advances in metal-induced oxidative stress and human disease. Toxicology 283(2-3):65-87. Epub 2011 Mar 23. Review

14. Ktari S, Arlet G, Mnif B, Gautier V, Mahjoubi F, Jmeaa MB, Bouaziz M, Hammami A (2006) Emergence of Multidrug-Resistant Klebsiella pneumoniae isolates pro- ducing VIM-4 Metallo- $\beta$-Lactamase, CTXM-15 Extended-Spectrum $\beta$-Lactamase, and CMY-4 AmpC $\beta$-Lactamase in a Tunisian University Hospital. Antimicrob Agents Chemother 50:4198-4201

15. Li TLC (2006) Taiwanese Native Medicinal Plants: Phytopharmacology and Therapeutic Values. CRC Press, FL

16. Lin PC, Bi WF, Lin CH, Lee FP, Yang LL (2013) Comparing different solvent extracts of Rhus semialata var. roxburghiana stem against ferrous ion-induced lipid peroxidation in mice liver mitochondria. Nat Prod Commun 8:621-625

17. Narasimhulu G, Mohamed J (2014) Medicinal Phytochemical And Pharmacological Properties Of Kesum (Polygonum Minus Linn.): A Mini Review. International Journal of Pharmacy Pharmaceutical Sciences 6:682-688

18. Nauman K, Arshad M (2011) Screening of aqueous methanol plant extracts for their antibacterial activity. In Science and Technology Against Microbial Pathogens: Research, Development and 
Evaluation, Proceedings of the International Conference on Antimicrobial Research (ICAR2010), Valladolid, Spain 3-5 November 2010 (p. 123). World Scientific

19. Pari L, Karthikeyan L, Karthika AP, Rathinam P (2015) Protective effects of hesperidin on oxidative stress, dyslipidaemia and histological changes in iron-induced hepatic and renal toxicity in rats. Toxicology Reports 2:46-55

20. Perez F, El Chakhtoura NG, Papp-Wallace KM, Wilson BM, Bonomo RA (2016) Treatment Options For Infections Caused By Carbapenem-Resistant Enterobacteriaceae: Can We Apply "Precision Medicine" To Antimicrobial Chemotherapy? Expert Opin Pharmacother 17:761-781

21. Rodríguez-Baño J, Navarro MD, Romero L, Martínez-Martínez L, Muniain MA, Perea EJ, Pascual A (2004) Epidemiology and clinical features of infections caused by extended-spectrum betalactamase-producing Escherichia coli in nonhospitalized patients. J Clin Microbiol 42:1089-1094

22. Sah SK, Rasool U, Hemalatha S (2019) Andrographis paniculata extract inhibit growth, biofilm formation in multidrug resistant strains of Klebsiella pneumoniae. Journal of Traditional Complementary Medicine 10:599-604

23. Shahghasi A, Shahidi GH, Fooladi MH, Mahdavi MJ (2004) Broadspectrim, a novel antibacterial from Streptomyces sp. Biotechnology 3:26-130

24. Shaik G, Sujatha N, Mehar SK (2014) Medicinal plants as source of antibacterial agents to counter Klebsiella pneumonia. Journal of Applied Pharmaceutical Science 4:135-147

25. Sharmeen R, Hossain N, Rahman M, Foysal J, Miah F (2012) International Current Pharmaceutical Journal In-vitro antibacterial activity of herbal aqueous extract against multi-drug resistant Klebsiella $s p$. isolated from human clinical samples. International Current Pharmaceutical Journal 1:133-137

26. Shu JC, Liu JQ, Zhong YQ (2012) Two new pterosin sesquiterpenes from Pteris multifida Poir. Phytochem Lett 5:276-279

27. Subba B, Sharma A, Budhathoki A (2016) Assessment of phytochemical content, antioxidant and antibacterial activities of three medicinal plants of Nepal. Journal of Medicinal Plants Research 10:829-837

28. Syed S, Fatima N, Kabeer G (2016) Portulaca Oleracea L.: A Mini Review On Phytochemistry And Phramacology. International Journal of Biology and Biotechnology 13:637-641

29. Tan SR, Gao J, Li OR, Guo TY, Dong ZS, Bai XH, Yang JH, Hao SM, He FF (2020) Synergistic effect of chlorogenic acid and levofloxacin against Klebsiella pneumonia infection in vitro and in vivo. Sci Rep 10:20013

30. Tepe B, Daferera D, Sökmen M, Polissiou M, Sökmen A (2004) In vitro antimicrobial and antioxidant activities of the essential oils and various extracts of Thymus eigii. J Agric Food Chem 52:11321137

31. Tsai SS, Huang JC, Chen ST, Sun JH, Wang CC, Lin SF, Hsu BR, Lin JD, Huang SY, Huang YY (2010) Characteristics of Klebsiella pneumoniae bacteremia in community-acquired and nosocomial infections in diabetic patients. Chang Gung Medical Journal 33:532-539 
32. Tsai SY, Tseng HF, Tan HF, Chien YS, Chang CC (2009) End-stage Renal Disease in Taiwan: A CaseControl Study. J Epidemiol 19:169-176. doi:10.2188/jea.JE20080099

33. Wei H, Shen J, Pang X, Ding D, Zhang Y, Zhang B, Lu H, Wang T, Zhang C, Hua X, Cui L, Zhao L (2008) Fatal infection in human flora-associated piglets caused by the opportunistic pathogen Klebsiella pneumoniae from an apparently healthy human donor. J Vet Med Sci 70:715-717

34. Williamson EM. China: Churchill Livingstone (2002) Major Herbs of Ayurveda

35. Who WHO (1993) Summary of WHO guidelines for assessment of herbal medicines. Herbal Gram 28:13-14

36. Yamac M, Bilgili F (2006) Antimicrobial activities of fruit bodies and/or mycelial cultures of some mushroom isolates. Pharm Biol 44:660-667

37. Yan JJ, Wen-Chien K, Shu-Huei T, Hsiu-Mei W, Jiunn-Jong W (2001) Outbreak of infection with Multidrug-Resistant Klebsiella pneumoniae carrying blalMP-8 in a university medical center in Taiwan. $J$ Clin Microbiol 39:4433-4439

38. Zhao Q, Chen XY, Martin C (2016) Scutellaria baicalensis, the golden herb from the garden of Chinese medicinal plants. Sci Bull 61:1391-1398

39. Zgoda JR, Porter JR (2001) A convenient microdilution method for screening natural products against bacteria and fungi. Pharm Biol 39:221-225

\section{Tables}

Table 1. Antibacterial effect of extracts from 20 Taiwanese plants 


\begin{tabular}{|c|c|c|c|c|}
\hline \multirow[t]{2}{*}{ Plant Extracts / Control (+ and -) } & \multicolumn{4}{|c|}{ MIC $(\mu \mathrm{g} / \mathrm{ml})$} \\
\hline & $\begin{array}{c}\text { Kp (ATCC) } \\
23856\end{array}$ & $\begin{array}{c}\text { Kp (ATCC) } \\
700603\end{array}$ & $\begin{array}{c}\text { E. Coli } \\
\text { (ATCC) } \\
25922\end{array}$ & $\begin{array}{c}\text { E. coli } \\
\text { (ATCC) } \\
35218\end{array}$ \\
\hline Polymyxin B sulfate salt & $\leqq 1$ & $\leqq 1$ & $\leqq 1$ & $\leqq 1$ \\
\hline Gentamycin & $\leqq 4$ & $\leqq 4$ & $\leqq 4$ & 16 \\
\hline $0.5 \%$ DMSO in PBS & - & - & $=-$ & - \\
\hline Amaranthus viridis Linn. & - & - & - & - \\
\hline Angelica dahurica var. formosana Yen & - & - & - & - \\
\hline $\begin{array}{l}\text { Bidens pilosa L. var. minor (blume) } \\
\text { Sherff }\end{array}$ & - & - & - & - \\
\hline $\begin{array}{l}\text { Broussonetia papyrifera (Linn) L'Herit. } \\
\text { Ex Vent. }\end{array}$ & - & - & - & - \\
\hline Centella asiatica L. & - & - & - & - \\
\hline $\begin{array}{l}\text { Equisetum ramosissimum subsp..debile } \\
\text { (Roxb.) Hauke. }\end{array}$ & - & - & - & - \\
\hline Euphorbia hirta L. & - & - & - & - \\
\hline Euphorbia thymifolia L. & - & - & - & - \\
\hline Eupatorium formosanum Hay. & - & - & - & - \\
\hline Kyllingia brevifolia Rottb. & - & - & - & - \\
\hline $\begin{array}{l}\text { Litsea Cubeba (Lour.qPers. Persoon } \\
\text { Actinodaphne citrata (Blume) Hayata }\end{array}$ & - & - & - & - \\
\hline Lygodium japonicum (Thunb.) Sw. & - & - & - & - \\
\hline Pinellia ternate (Thunb.) Breit. & - & - & - & - \\
\hline Plantago asiatica L. & - & - & - & - \\
\hline Polygonum perfoliuatum Linn. & - & - & - & - \\
\hline Portulaca oleracea var. sativa DC. & - & - & - & - \\
\hline Pteris multifida Poir. & - & - & - & - \\
\hline Rhus semialata var. roxburghiana DC. & + & - & - & - \\
\hline Serissa japonica (Thunb.) Thunb. & - & - & - & - \\
\hline Urena lobata L. & - & - & - & - \\
\hline
\end{tabular}

+: inhibition to bacteria growth; - : no inhibition to bacteria growth

Table 2. Minimum Inhibitory Concentrations (MICs) of each RSR extracts ( $\mu \mathrm{g} / \mathrm{mL}$ ) Extract $n$-hexaneEAAcetoneEthanolH ${ }_{2} \mathrm{OAcetone}^{\mathrm{EA}}$

\begin{tabular}{|c|c|c|c|c|c|c|}
\hline & & & & & & MIC $(\mu \mathrm{g} / \mathrm{ml})$ \\
\hline Kp (ATCC) 23856 & + & + & + & + & + & $500 \quad 250$ \\
\hline Kp (АТСС) 700603 & + & + & + & - & + & 1000 \\
\hline E. coli (ATCC) 25922, & + & + & + & - & - & 1000 \\
\hline E. coli (ATCC) 35218 & - & + & + & - & - & $>1000$ \\
\hline
\end{tabular}

Table 3. Minimum inhibitory concentration (MIC, $\mu \mathrm{g} / \mathrm{ml}$ ) of RSR acetone extract and positive antibiotis against standard strains and clinically isolated $K p$ and E.coli strains 


\begin{tabular}{|c|c|c|c|c|c|c|}
\hline$\overline{K p}$ & & & nl) & & & $\mathrm{C}(\mu \mathrm{g} / \mathrm{ml})$ \\
\hline *AТСС 700603 & - & 1 & $>16$ & $>16$ & + & 1000 \\
\hline *ATCC 23856 & - & 0.25 & $>16$ & $\leqq 0.5$ & + & 500 \\
\hline 1520914 & - & 0.5 & $>16$ & 64 & + & 1000 \\
\hline 1527226 & - & 1 & $>16$ & 128 & + & 750 \\
\hline 1527920 & - & 0.5 & $>16$ & 64 & + & 1000 \\
\hline 1520160-1 & - & 0.5 & $>16$ & 128 & + & 1000 \\
\hline 1521656 & - & 0.5 & $>16$ & 1 & + & 750 \\
\hline 1522657 & - & 0.5 & $>16$ & 32 & + & 1000 \\
\hline 1523941 & - & 0.5 & $>16$ & 128 & + & 1000 \\
\hline 1524581 & - & 0.5 & $>16$ & $>128$ & + & 1000 \\
\hline 1526783 & - & 0.5 & $>16$ & 64 & + & 1000 \\
\hline 1543407 & - & 0.5 & $>16$ & 64 & + & 1000 \\
\hline 1541487 & - & $>16$ & $>16$ & $>128$ & + & $>1000$ \\
\hline 1542299 & - & 0.5 & $>16$ & $\leqq 0.5$ & + & $>1000$ \\
\hline 1545756 & - & 0.5 & $>16$ & $\leqq 0.5$ & + & $>1000$ \\
\hline 80 & - & 0.5 & $>16$ & $>128$ & + & 750 \\
\hline 81 & - & 0.25 & $>16$ & $>128$ & + & 1000 \\
\hline 91 & - & 0.5 & $>16$ & 64 & + & 750 \\
\hline 98 & - & 0.5 & $>16$ & 16 & + & 500 \\
\hline E. Coli & & & & & & \\
\hline *ATCC 25922 & - & 0.5 & $>16$ & 1 & + & 1000 \\
\hline *ATCC 35218 & - & 0.25 & $>16$ & 1 & + & 1000 \\
\hline 1526829 & - & 0.25 & $>16$ & $>128$ & + & 1000 \\
\hline 1522652 & - & 0.25 & $>16$ & 2 & + & 750 \\
\hline 1530404 & - & 0.25 & $>16$ & $>128$ & + & 750 \\
\hline 1521949 & - & 0.25 & $>16$ & $>128$ & + & 750 \\
\hline 1521624 & - & $\leqq 0.125$ & $>16$ & $>128$ & + & 1000 \\
\hline 1521569 & - & 0.25 & $>16$ & 128 & + & 1000 \\
\hline 1530090 & - & 0.25 & $>16$ & 1 & + & 1000 \\
\hline 1520331 & - & 0.25 & $>16$ & 64 & + & 750 \\
\hline 1520641 & - & 0.25 & $>16$ & 2 & + & 750 \\
\hline 1522991 & - & 0.25 & $>16$ & 128 & + & 1000 \\
\hline 1522953 & - & 0.25 & $>16$ & 1 & + & 500 \\
\hline 1519678 & - & 0.25 & $>16$ & 1 & + & 750 \\
\hline 1520264 & - & 0.25 & $>16$ & 64 & + & 500 \\
\hline 1527958 & - & 0.25 & $>16$ & 1 & + & 1000 \\
\hline 1528051 & - & 0.25 & $>16$ & 1 & + & 500 \\
\hline 1527082 & - & 0.25 & $>16$ & 1 & + & 1000 \\
\hline
\end{tabular}

* Antibacterial activity to standard strain

$K p-\mathrm{MIC}_{50}: 1000 \mu \mathrm{g} / \mathrm{ml} ; \mathrm{MIC}_{90}:>1000 \mu \mathrm{g} / \mathrm{ml} ;$ E.coli- $\mathrm{MIC}_{50}: 750 \mu \mathrm{g} / \mathrm{ml} ; \mathrm{MIC}_{90}: 1000 \mu \mathrm{g} / \mathrm{ml}$ +: inhibition to bacteria growth; -: no inhibition to bacteria growth 
Table 4. Inhibitory effect $\mathrm{IC}_{50}(\mu \mathrm{g} / \mathrm{mL})$ of RSR acetone extract to ferrous ion-induced LPO on mice kidney mitochondria

\begin{tabular}{c|c}
\hline & $\mathrm{IC}_{50}(\boldsymbol{\mu g} / \mathrm{ml})$ \\
\hline RSR acetone extract & $29.29 \pm 0.35$ \\
\hline Gallic acid & $27.07 \pm 6.61$ \\
\hline Trolox & $4.44 \pm 0.23$ \\
\hline
\end{tabular}

Positive control agents are Gallic acid and Trolox

Table 5- Antibacterial spectrum range of RSR acetone extract against other 24 kinds of microbial strains

\section{Figures}

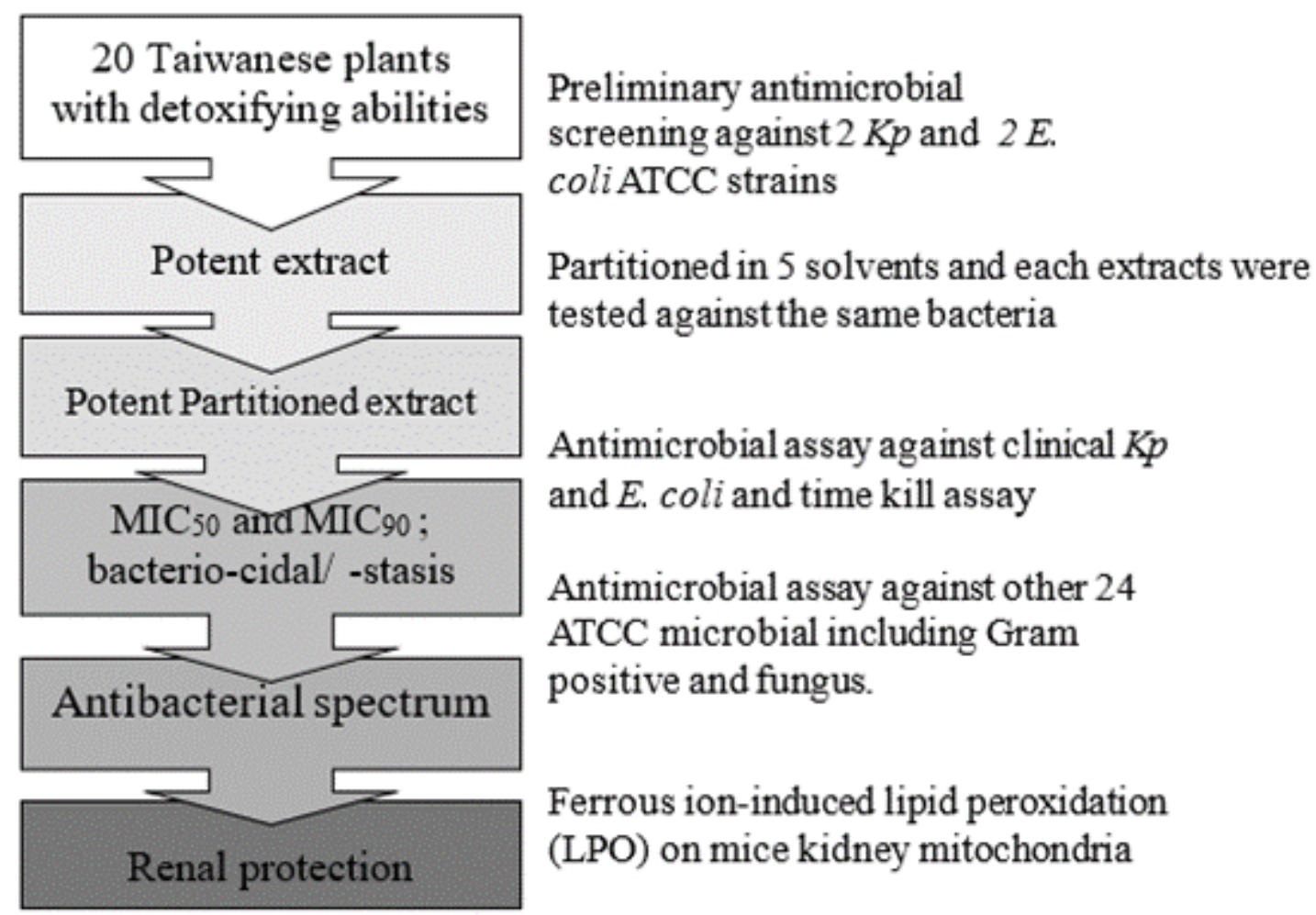

\section{Figure 1}

The flow chart of antibacterial capability against Kp and E. coli detection procedure and renal damage protective effect. 


\begin{tabular}{|c|c|c|c|c|c|c|}
\hline \multirow[t]{2}{*}{ Bacteria } & \multirow[t]{2}{*}{ Strain } & \multirow[t]{2}{*}{$\begin{array}{l}+/ \text { - Bacterium } \\
\text { or fungus }\end{array}$} & \multirow[t]{2}{*}{ DMSO } & \multirow{2}{*}{\multicolumn{2}{|c|}{$\begin{array}{c}\begin{array}{l}\text { polymyxin B Gentamycin } \\
\text { sulfate salt }\end{array} \\
\text { MIC }(\mu \mathrm{g} / \mathrm{ml})\end{array}$}} & \multirow[t]{2}{*}{$\begin{array}{c}\text { RSR } \\
\text { Acetone } \\
\text { extract }\end{array}$} \\
\hline & & & & & & \\
\hline MSSA & $\begin{array}{l}\text { ATCC } \\
29213\end{array}$ & $(+)$ & - & $>16$ & $\leqq 4$ & + \\
\hline MRSA & $85 / 2082$ & $(+)$ & - & $>16$ & $\leqq 4$ & + \\
\hline hVISA & Mu3 & $(+)$ & - & $>16$ & $>128$ & + \\
\hline VISA & Mu50 & $(+)$ & - & $>16$ & $>128$ & + \\
\hline $\begin{array}{l}\text { Staphylococcus } \\
\text { epidermidis }\end{array}$ & $\begin{array}{l}\text { ATCC } \\
12228\end{array}$ & $(+)$ & - & 8 & $\leqq 4$ & + \\
\hline $\begin{array}{l}\text { Group } \\
\text { B streptococcus }\end{array}$ & $\begin{array}{l}\text { ATCC } \\
12401\end{array}$ & $(+)$ & - & $>16$ & 128 & + \\
\hline $\begin{array}{l}\text { Enterococcus } \\
\text { faecalis }\end{array}$ & $\begin{array}{l}\text { ATCC } \\
29212\end{array}$ & $(+)$ & - & $>16$ & 16 & + \\
\hline $\begin{array}{l}\text { Enterococcus } \\
\text { faecalis }\end{array}$ & $\begin{array}{l}\text { ATCC } \\
51299\end{array}$ & $(+)$ & - & $>16$ & $>128$ & + \\
\hline $\begin{array}{l}\text { Pseudomonas } \\
\text { aeruqinosa }\end{array}$ & $\begin{array}{l}\text { ATCC } \\
14207\end{array}$ & $(-)$ & - & $\leqq 1$ & $\leqq 4$ & + \\
\hline$P$. aeruginosa & $\begin{array}{l}\text { ATCC } \\
27853\end{array}$ & $(-)$ & - & 2 & $\leqq 4$ & + \\
\hline $\begin{array}{c}\text { Samonella enteric } \\
\text { Typhimurium }\end{array}$ & $\begin{array}{l}\text { ATCC } \\
13076\end{array}$ & $(-)$ & - & $\leqq 1$ & $\leqq 4$ & + \\
\hline $\begin{array}{l}\text { Samonella } \\
\text { multivorum }\end{array}$ & $\begin{array}{l}\text { ATCC } \\
35656\end{array}$ & $(-)$ & + & $>16$ & 64 & + \\
\hline $\begin{array}{c}\text { Samonella } \\
\text { typhimurium }\end{array}$ & $\begin{array}{l}\text { ATCC } \\
13311\end{array}$ & $(-)$ & - & $\leqq 1$ & $\leqq 4$ & + \\
\hline $\begin{array}{c}\text { Samonella } \\
\text { paratvphi (A) }\end{array}$ & $\begin{array}{l}\text { ATCC } \\
0150\end{array}$ & $(-)$ & - & $\leqq 1$ & $\leqq 4$ & + \\
\hline Samonella & ATCC & $(-)$ & - & $\leqq 1$ & $\leqq 4$ & + \\
\hline Samonella. & ATCC & $(-)$ & - & $\leqq 1$ & $\leqq 4$ & + \\
\hline $\begin{array}{l}\text { Choleraesusis } \\
\text { Samonella }\end{array}$ & $\begin{array}{l}10744 \\
\text { ATCC }\end{array}$ & $(-)$ & - & $\leqq 1$ & $\leq 4$ & + \\
\hline choleraesusis & 115462 & & & & & \\
\hline Shigella boydii & $\begin{array}{l}\text { ATCC } \\
9207\end{array}$ & $(-)$ & - & $>16$ & $>128$ & + \\
\hline Shigella dysenteriae & $\begin{array}{l}\text { ATCC } \\
13983\end{array}$ & $(-)$ & - & $\leqq 1$ & $\leqq 4$ & + \\
\hline Shigella flexneri & $\begin{array}{l}\text { ATCC } \\
10772\end{array}$ & $(-)$ & - & $\leqq 1$ & $\leqq 4$ & + \\
\hline Shigella sonnei & $\begin{array}{l}\text { ATCC } \\
15965\end{array}$ & $(-)$ & - & $\leqq 1$ & $\leqq 4$ & + \\
\hline Shigella sonnei & $\begin{array}{l}\text { ATCC } \\
25931\end{array}$ & $(-)$ & - & $\leqq 1$ & $\leqq 4$ & + \\
\hline Candida albicans & $\begin{array}{l}\text { ATCC } \\
90018\end{array}$ & fungus & + & $>16$ & 128 & + \\
\hline Candida parapsilosis & $\begin{array}{l}\text { ATCC } \\
22019\end{array}$ & fungus & + & $>16$ & $>128$ & + \\
\hline
\end{tabular}

+: inhibition to bacteria growth; - : no inhibition to bacteria growth

, Control:0.5\%DMSO and Positive control agents :polymyxin B sulfate salt, gentamycin 

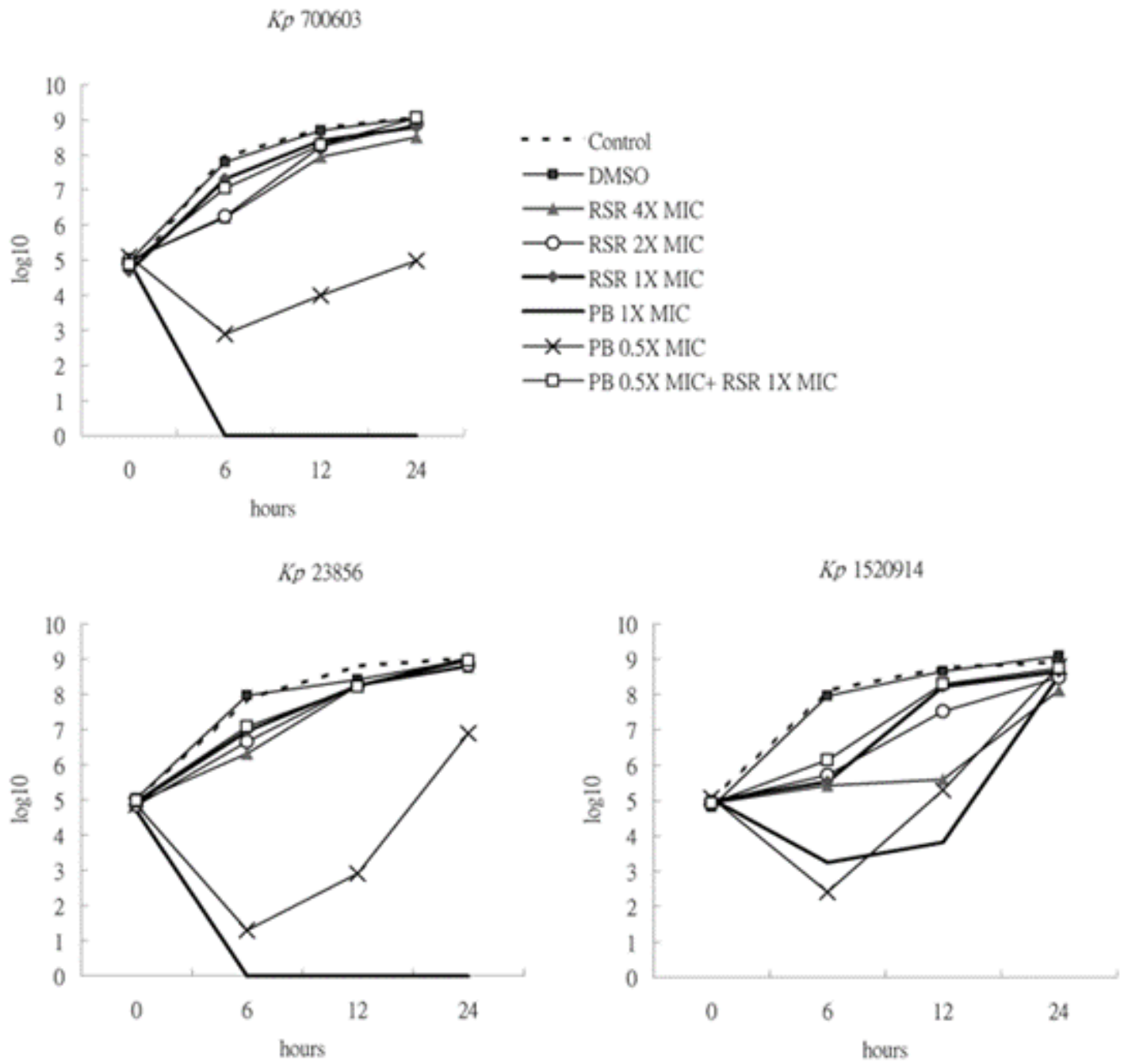

Figure 2

Time-kill kinetics of RSR acetone extract, $1 \mathrm{~mL}$ DMSO (- control) and polymyxin B sulfate salt (PB) (+ control) against Kp (ATCC) 700603, (ATCC) 23856 and clinical ESBL-Kp 1520914 

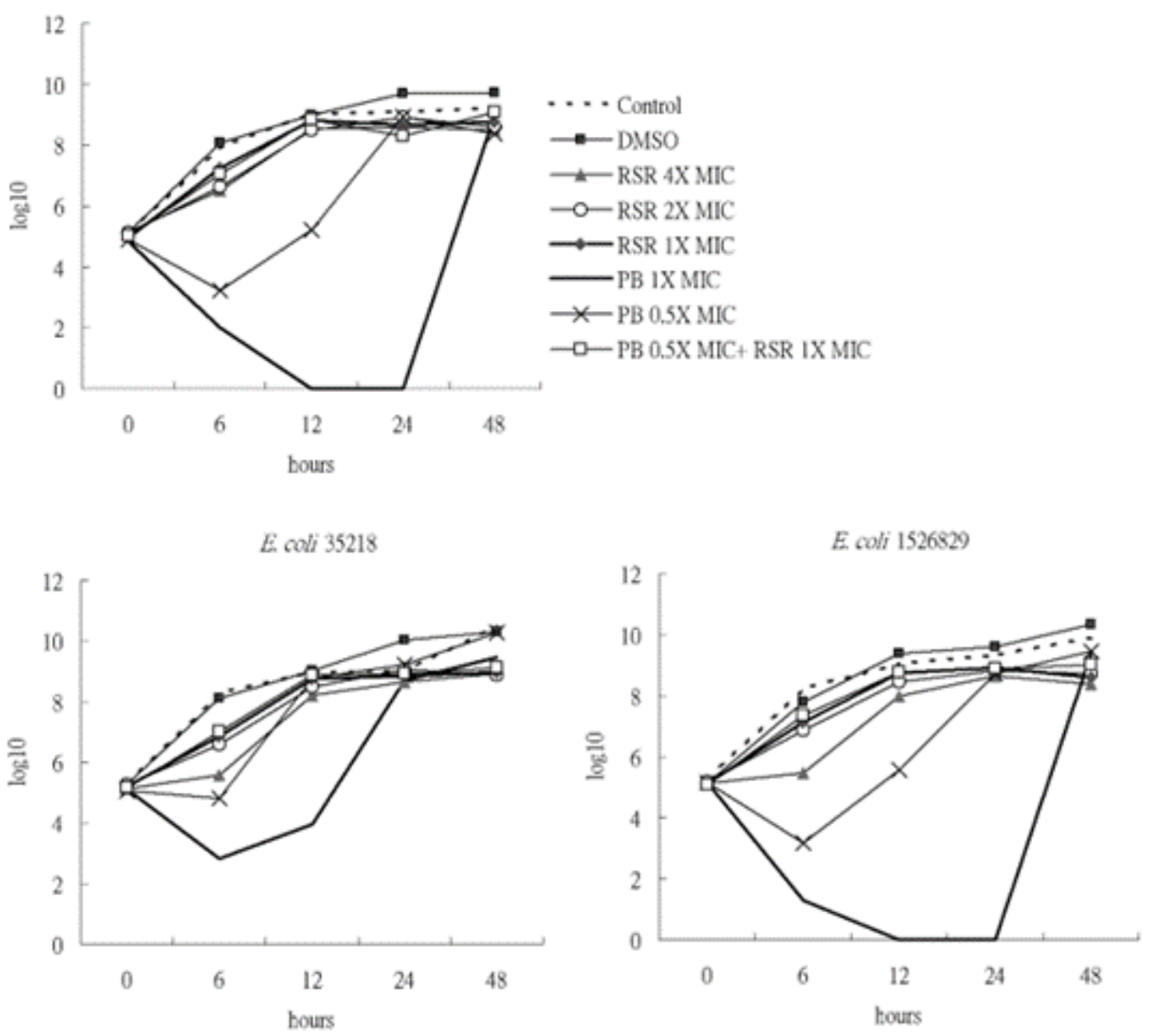

\section{Figure 3}

Time-kill kinetics of RSR acetone extract, $1 \mathrm{~mL}$ DMSO (control) and polymyxin B sulfate salt (PB) against E. coli (ATCC) 25922, (ATCC) 35218, and clinical ESBL- E. coli 1526829 